\title{
O PEWNEJ REDUKCJI ILOŚCI POJĘĆ PIERWOTNYCH FONOLOGII
}

\author{
(Streszczenie)
}

Sformalizowany system fonologii teoretycznej wyłożony w mojej książce [1] jest oparty na trzech swoiście fonetycznych terminach pierwotnych oraz na piętnastu charakteryzujących je aksjomatach $\mathrm{Al}-\mathrm{Al5}$. Te trzy terminy pierwotne to I (klasa wszystkich idiolektów), $\mathbf{K}$ (klasa wszystkich rodzajów cech fonetycznych) oraz $\mathbf{O}$ (klasa wszystkich pauz).

W nocie obecnej wykazuje się, że po wprowadzeniu do systemu pewnej drobnej zmiany, termin $\mathbf{O}$ staje się definiowalny za pomocą pozostałych terminów pierwotnych. Wspomniana zmiana polega na dolączeniu następującego prostego aksjomatu:

A16.

$$
u \in \bigcup \mathbf{I} \wedge x, y \in \mathbf{O} \cap \mathbf{P}^{\mathrm{v}} u \rightarrow \sim x \mathbf{T}_{\mathrm{i}} \boldsymbol{y}
$$

Pokazuje się też, że układ aksjomatów dla tak zmodyfikowanego systemu daje się nieco uprościć: jeśli mianowicie symbol $\mathbf{O}$ zostanie wprowadzony za pomocą odpowiedniej definicji, to aksjomaty A4, A11 i A16 można po prostu pominąć, gdyż będą one konsekwencjami aksjomatów pozostałych.

Warto tu jeszcze dodać, że przyjęcie aksjomatu A16 jest zupełnie nieistotne $z$ intuicyjno-lingwistycznego punktu widzenia. 